\title{
A POÉTICA DO VIVIDO: UMA ETNOGRAFIA DO COTIDIANO NA CIDADE BAIXA - POA/RS
}

Flávio Leonel Abreu da Silveira

O bairro, o edifício, as esquinas...

"Os dias passam ao lado

o sol passa ao lado de quem desceu as escadas..." Com Ansiedade - Francisco Alvim

O bairro Cidade Baixa é uma área de Porto Alegre que resguarda parte da memória das populações negras no espaço urbano, mas também de uma boêmia porto-alegrense, de estilos de vida que, ao longo do tempo, na medida que a dinâmica de ocupação e transformação do mesmo foi ocorrendo, possibilitaram que esse local tomasse as feições que adquiriu na atualidade. A isso relacionam-se as modas que se sucederam de maneira a imprimir características diversas à paisagem urbana, seja nas formas que a arquitetura revela através dos muitos estilos das construções que convivem entre si, configurando um cenário singular, seja pela diversidade de atores sociais e grupos humanos que transitam por ele, onde a estética ligada ao vestir, por exemplo, revela comportamentos e formas de associações entre grupos que se alteram com o tempo, com aquilo que é próprio de cada época, da vida social existente no bairro.

Sendo assim, os personagens urbanos que constituem o corpo social que pulsa no bairro trazem consigo uma maior ou menor inserção e, por isso, permanência no local, engendrando processos microscópicos de interação, ocupando nichos específicos - aqui, a relação com a ecologia é direta (uma ecologia urbana) - no sentido de desempenharem papéis importantes na dinâmica do bairro através de interações da ordem do simbólico que demarcam espaços do habitar, da labuta, do lazer, da busca do alimento, entre outras possibilidades. Portanto, há um óbvio caráter relacional - e porque não, ecossistêmico -, de interação proxêmica, de diálogo e permuta entre diversas instâncias das práticas sociais que se revelam possíveis no mesmo.

A Cidade Baixa, nessa perspectiva, é esse espaço urbano que traz em si uma dimensão polissêmica (e polimórfica) onde grupos circulam e interagem: do menino de rua que cheira loló sentado no muro de uma casa ao punk tatuado e repleto de piercings que exibe sua cabeleira espetada; do rastafari de longas tranças que compra pãezinhos ao lado da vovó numa padaria de classe média; dos taxistas que se agrupam em torno de seus automóveis à moradora de 
rua que sorri banguela para mim sentada na calçada junto aos seus pertences - temos um universo cultural extremamente rico e promissor no que tange a produção de formas peculiares de relações sociais e sociabilidade no contexto citadino atores sociais que por ali circulam, portanto, ao apresentarem inserções variadas na paisagem do bairro, através de suas ações cotidianas, imprimem uma dinâmica que se constitui de cenas singelas e comuns, pelo fato de que transitam no local como personagens em deriva através das ruas, no sentido de uma cidade que se constitui também no andar, naquilo que a rua oferta em termos de possibilidade de experienciar a esfera do público - no deslocamento que pode representar apenas uma espécie de circularidade por bares, ou trânsito de um bairro a outro -, mas também, enquanto espaço que resguarda certa fixidez, de convivência, de construção das redes de relações e produção de cultura na cidade.

Então, é nesse jogo de ir e vir, de permanecer e se lançar, de uma indiferença que se concretiza na velocidade dos corpos em deriva ou na satisfação oriunda da conversa amigável, do encontro onde se comenta as amenidades ou a crueza do vivido que os atores sociais se entregam de alguma forma a aventura urbana que os seus trajetos cotidianos (e as trajetórias individuais que a eles estão conectadas) se configuram como potência, como o possível na construção da vida social: do homem na multidão de Poe, a percorrer os meandros da cidade de maneira a vivê-la na sua intensidade (misteriosa, resguardando certos perigos) ao olhar blasé apontado pela perspectiva simmeliana ou, do flanêur que se encanta com os cafés e restaurantes (como Baudelaire ou Gautier) cuja importância Benjamin nos lembra no que concerne a percepção da sutileza de uma estética citadina, temos que a cidade na sua dinâmica de imagens, também pode conter laços afetuais, pontuais, como coloca Maffesoli, ou ainda, de um formismo peculiar que se adere a um estar-junto em criação: a cidade existe enquanto um cenário cuja poética ao oferecer-se ao olhar que se encanta e se entrega a sua sutileza, permite que a observemos como um corpo complexo gerando ordens a partir do que se apresenta, de certa forma, a um primeiro olhar, como caótico.

Como morador do bairro que, ao longo dos últimos dois anos vem acompanhando com maior ou menor intensidade a sua dinâmica cultural, enquanto um ator social que integra essa paisagem que é significativa dentro da geografia urbana da cidade de Porto Alegre, as minhas observações acerca do bairro estão relacionadas, portanto, ao estranhamento do familiar como uma forma de estabelecer o distanciamento metodológico que permite lançar um olhar atento sobre aspectos da vida social presente em tal contexto, de exoticizar o familiar - e exercer o 
anthropological blues que aponta DaMatta seguindo os ritmos, os tons, fluindo entre as formas que a cidade oferta quando se realiza um mergulho em sua poética - de maneira a perceber a riqueza existente no cotidiano na-da cidade.

$\mathrm{Ou}$ ainda, de experimentar aquilo que é uma questão fundamental colocada pela Antropologia Urbana produzida no Brasil, especialmente, através dos trabalhos de Gilberto Velho (1985; 1994a; 1994b), mas também de outros antropólogos, ou seja, de que o antropólogo deve ser capaz de interpretar aqueles acontecimentos que são significativos para realizar uma tradução da vida social nas cidades brasileiras, de estar atento para os fenômenos sociais relacionados a produção de heterogeneidade cultural e de configuração de arranjos sociais singulares que são próprios do contexto urbano, dada a complexidade de sentidos que são produzidos nas várias ambiências que aparecem no mesmo, e que, Porto Alegre, enquanto um locus privilegiado não representa uma exceção.

O fato de morar em um edifício que é uma espécie de "balança" - ele mesmo consistindo em um cenário interessante de diversidade cultural - me coloca como alguém que experiencia o rico universo que constitui o cotidiano de uma cidade como Porto Alegre, naquilo que ela possui de peculiar em seus espaços de sociabilidade, de produção de formas singulares de interação social ou de conflitos, de tudo o que o meio urbano na sua intensa agitação e acomodação de imagens, sentidos, denuncia nas manifestações do animal humano, de algo que surge a partir do cadinho cultural, onde mesclam-se através de uma alquimia original, práticas sociais diversas que podem representar o belo existir das formas na associação de pessoas ou do perverso que é próprio das ações humanas quando se toma a arena social como um campo de batalha.

Portanto, o edifício Spartacus onde moro, com cerca de 261 apartamentos e, pelo que me informaram construído na década de 60 para ser um hospital - está localizado no aglomerado de prédios comerciais e edifícios de moradia que compõe a quadra localizada entre o Largo da EPATUR e a Rua da República. É exatamente nesse ponto do bairro que se localiza a Padaria Suíça que é a ambiência onde busco acompanhar certas práticas ligadas ao mundo do trabalho, mas também, formas bastante peculiares de sociabilidade no bairro Cidade Baixa. Entre o Spartacus e a padaria existe, primeiramente, o diretório de um candidato a vereador pelo PT e, como este, existem pelo menos mais dois em questão de uma quadra - a inauguração recente do espaço representou uma movimentação na área, com a presença de balões vermelhos, cartazes e pessoas com adesivos do candidato aderidos à roupa -, em seguida, 
existe uma lotérica e, finalmente, a padaria. Trata-se, mais especificamente, de um estabelecimento situado na altura em que a rua Sarmento Leite desemboca na avenida José do Patrocínio.

\section{A padaria}

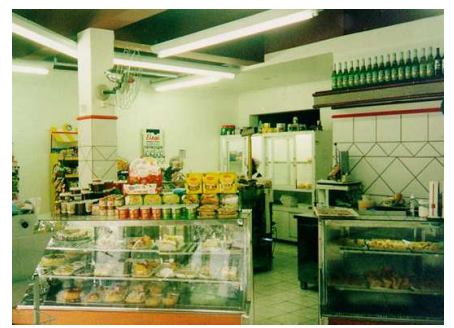

"O ritual diário

(...) me lança fora" João Carlos Pádua

A Padaria Suíça tem as cores nacionais desse país na sua decoração, pois os azulejos

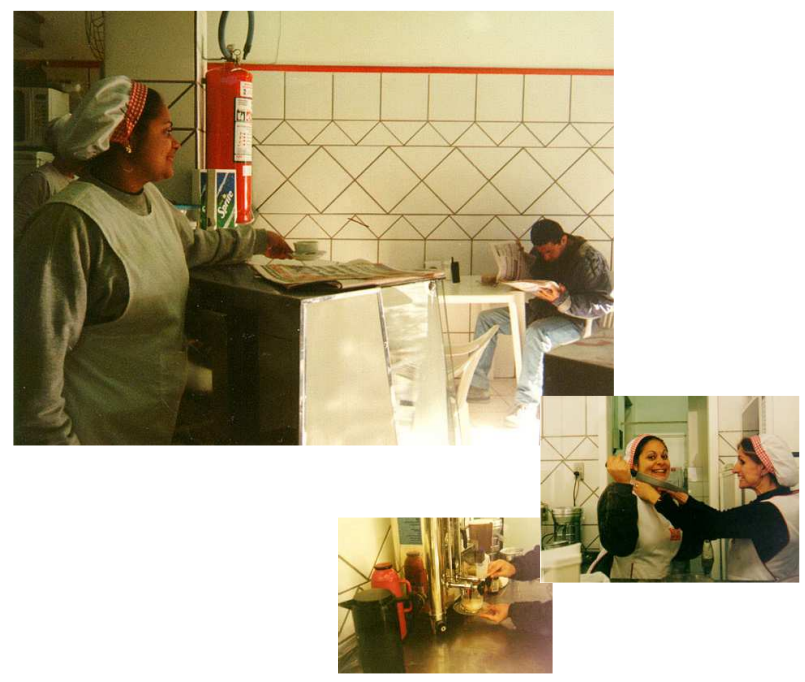

brancos contrastam com os detalhes vermelhos entre eles, a placa que anuncia o nome do estabelecimento também tem a mesma coloração, onde aparecem croissants desenhados. Augusto, um dos dois sócios do estabelecimento, me diria que o nome Suíça é em homenagem aos seus antepassados, mais especificamente, ao seu avô que migrara desse país para o Brasil. Ele também é uma espécie de migrante, pois é curitibano - antes fora dono de um hotel na rua Barros Cassal que se chamava Curitibano - e, segundo ele, já foi dono de nove restaurantes, além de ser proprietário de um Pesque Pague localizado próximo de Barra do Ribeiro, inclusive, me mostrou 
uma série de fotografias do local.

A padaria é bastante simpática, a brancura excessiva dos azulejos chama a atenção, dando uma impressão de assepcia e, o contraste com o vermelho dos detalhes, torna o conjunto agradável ao olhar: logo que se entra no estabelecimento depara-se com os balcões com vidros em cujo interior encontram-se os quitutes - doces e salgados - que ficam à mostra, como se oferecendo a quem chega; sobre os balcões uma infinidade de caixas multicoloridas de diversos produtos anuncia as possibilidades de consumo, noutros balcões mais à esquerda, os laticínios e fiambres resguardam-se sob o vidro geralmente úmido, refrigerado. Sobre eles croissants, pãezinhos de todos os tipos e formatos permanecem também como se oferecendo ao olhar. Atrás do balcão entre o espaço de circulação e a parede há uma espécie de armário que lembra aqueles de armazéns antigos onde os cacetinhos misturam-se caóticos.

$\mathrm{Na}$ esquerda ainda, estão os leites-longa-vida empilhados, ao lado, a caixa- registradora permanece, como o espaço no qual a permuta ocorre, onde a circularidade do dinheiro se evidencia. Esse é o local dos donos do estabelecimento por excelência, não que eles permaneçam presos ali, mas, geralmente, encarregam-se dos pagamentos dos produtos (com exceção de Sabrina, uma das funcionárias, não vi nenhum outro realizar tal tarefa); ao lado da caixaregistradora existe um freezer onde refrigerantes ficam à mostra. No lado direito há um freezer que delimita um espaço exígüo onde encontram-se quatro conjuntos de cadeiras e mesas de plástico branco, leitosos, no qual os freqüentadores do local permanecem realizando seus lanches. Finalmente, junto às paredes que delimitam a entrada da padaria existe um freezer e uma máquina caça-níqueis com algumas figuras meio monstruosas e luzes que movimentam-se (talvez em sentido horário). Próxima ao vão de entrada, mas na direita, uma grande janela apresenta o interior ao passante.

\section{O cotidiano na padaria}

"Fechou o jornal:

A brasa do cigarro

Ficou intensamente rubra

Junto à janela

O olho do cinzeiro se

Fixou em seus pensamentos

A mão desceu até um pouco mais baixo

A noite começava a se debruçar

Sobre os edifícios..."

Poema Absurdo - João Carlos Pádua 
Dado o aspecto pontual, microscópico, situacional de minhas observações (que ocorreram no mês de julho) a forma que encontrei de exprimi-las, ou ainda, de narrá-las, relaciona-se com minha preocupação de não torná-las uniformes demais - pois mesmo que, de certa maneira, existam padrões, comportamentos que se repetem cotidianamente, há uma singularidade em cada acontecimento, resguardando por isso algo de novidade, que a repetição não consegue eliminar -, sendo assim, ficaria muito linear se me propusesse a construir uma narrativa etnográfica de maneira que esse rico universo aparecesse como um texto acabado. Portanto, me parece mais interessante apresentar tais observações sob a forma de tópicos que dão a idéia da dinâmica pontual, das relações efêmeras, das trocas de palavras e olhares que em conjunto (e num sentido mais amplo, abarcando certa heterogeneidade) dão o tom da dinâmica no interior da padaria.

Sigo, dessa forma, o exemplo de Hélio Silva em seus dois brilhantes livros: em "Outras Cariocas", o autor se utiliza de asteriscos em dado momento para fazer reflexões (e mencionar certas impressões de sua vivência no campo), no entanto, aqui me proponho utilizar a estratégia como um recurso estilístico, mas também, como uma forma de lidar com aquilo que se denomina "fissuras intertextuais", ou seja, me proponho realizar um jogo entre fotografias e texto tentando evitar as possíveis quebras na narrativa que uma má utilização das mesmas poderia acarretar na continuidade do texto. Parto do princípio que a quebra do texto o constitui enquanto tal. Por outro lado, no anexo, onde experimento a sensação de umflanêur na Cidade Baixa me utilizo da divisão que Hélio Silva apresenta em seu "Travesti a invenção do feminino" entre dia e noite. De alguma forma, também faço referência aos regimes de imagens colocados por Gilbert Durand em "As Estruturas Antropológicas do Imaginário".

\section{Do olhar}

* Privilegio a manhã em minhas observações etnográficas pelo fato de que o tomar café nesse período do dia se reveste de um sentido outro que, no meu ponto de vista, tem relação com um tipo de ação culturalmente aprendida - um hábito matinal -, uma forma de lidar com o cotidiano que está relacionada a práticas que são importantes no processo de socialização das pessoas desde as relações familiares - pelo menos desde a infância que o café da manhã nos é colocado como uma prática cultural que nos constitui como sujeitos que lidam com técnicas 
corporais, com um tipo de interação comensal que é culturalmente engendrada. Trata-se da primeira refeição do dia e, certamente, apresenta importância variada para cada pessoa que a põe em prática.

* Numa manhã fria, um pouco escuro ainda, aproximadamente sete horas e quinze minutos, estou sentado como de costume junto à mesa tomando uma taça de café preto, existe um clima de camaradagem no ar e estão presentes no local: Fabiane a funcionária que atende no balcão (sempre preocupada com a execução de suas tarefas), Augusto (um dos dois donos que está junto à caixa-registradora) e dois senhores - um deles muito magro está sentado, permanecendo em silêncio (por vezes meio cabisbaixo, lançando um sorriso com a boca semiaberta), porém atento ao discurso do outro senhor que, em pé, gesticula e fala com eloquiência num tom bastante alto - há uma certa teatralidade no espaço que imprime um clima jocoso, risível - dada a performatividade presente no jogo de palavras, acompanhadas de expressões faciais e certos movimentos do corpo que tal senhor executa.

Meu diálogo com o grupo se dá através do olhar e dos sorrisos que lanço na medida que me envolvo enquanto co-participante na interação que ali ocorre, de alguma forma me introduzo na conversa entre amigos, como uma espécie de estranho que é familiar, posto que faço parte do cenário em certos momentos do dia, que também sou um cliente do estabelecimento. Em um determinado instante o senhor que está em pé me pergunta o que faço, ao dizer que estudo antropologia na UFRGS ele se mostra atento, dizendo que a antropologia é interessante e que tem um sobrinho que estuda na UFRGS, mas que "já tá tanto tempo que vai... aquilo?... ", ser jubilado, afirmo, "isso!", concorda. Digo ainda que sou professor - talvez para me justificar perante o grupo, por saber que há uma visão de determinadas pessoas que associam o "apenas" estudar como coisa de vagabundo. Em seguida me diz que é casado com uma professora aposentada, doutora (ele também teria sido professor de matemática), que, segundo sua afirmação, recebe uma aposentadoria mais elevada que a dele, também ex-policial civil. A partir de tal constatação, faz uma reflexão sobre a ética na polícia e, prontamente, diz que não fala para ninguém que se aposentou como policial. Depois, rindo, aponta para o que está sentado "E tu também!", seguindose então algumas gargalhadas do grupo. Trata-se de uma questão banal, diria que comum, mas prenhe de sentidos, onde se percebe a existência de uma cumplicidade que permite uma reflexão bem-humorada das vicissitudes cotidianas a partir do que há de risível nelas.

* Noutro dia, encontro o mesmo senhor falando com outro homem, um negro que toma café tranqüilamente. Inicia-se um diálogo meio tenso entre eles, percebo que foram colegas na 
polícia pelo fato de que comentam acerca do trabalho que realizaram. O homem negro meio irritado manda que ele pare de falar alto acerca do passado de policial dele: "vai negar isso!", diz o senhor ao outro, enquanto dá um cigarro a ele. Afastam-se meio estranhados.

* A manhã está quente, ensolarada, estou junto ao balcão. O senhor sentado, com certa idade tem um chapéu na cabeça, Fabiane se aproxima e cochicha no meu ouvido: "não gosto de atender aquele senhor, ele fede!"

* Ontem Fabiane (o nome foi sugerido por ela) estava com dor no corpo, seu rosto externava sinais de dor. Uma torção em alguma parte de seu tronco ou tórax, não sei ao certo. Mesmo assim, passava com o auxílio da vassoura um pano úmido no chão. Em algum momento externou sua dor ao grupo. Augusto que conversava com Marcos, o outro sócio, fez alusão em tom jocoso que teria se machucado na cama durante o ato sexual - risos no grupo. Fabiane, um pouco encabulada, mas sorrindo, responde que teria sido na cama, mas não daquela maneira.

* Uma das funcionárias do balcão é Sabrina (o nome foi sugerido por ela), a cigana. Sempre de vestido longo e rodado, com grandes brincos nas orelhas e muitos anéis nos dedos. Mantém uma sensualidade no olhar, envolvente, sutilezas muito próprias da sedução de uma mulher madura. É bastante simpática no atendimento dos fregueses, dá um tom íntimo a fala quando interpela, o quase sempre, indeciso comprador: "o que você quer querido (a)?"

Certo dia me mostrou no balcão as suas fotos vestida de Tiazinha - um maiô negro, meias negras, cintas ligas, saltos altos, o chicotinho e a máscara - uma pose sexy, silhueta bem desenhada, seios fartos e nádegas redondas, formas orgânicas no cenário montado para a fotografia. Ela me lembrava mais o tipo de sensualidade de uma chacrete do que a da Tiazinha. Em outras fotos, em trajes menos íntimos, mas nem por isso menos erotizada olhava com firmeza para a câmera - uma beleza exótica em um clima cafona - cortinas vinho muito longas com detalhes, se não me engano, em dourado, alguns objetos ao fundo. Além das fotografias que tinha tirado num determinado hotel (que pertencera a Augusto), havia fotos de família, seu universo doméstico: "tenho seis filhos e sou avó!"

* Pela tarde, passei na padaria para tomar o meu café. Augusto, como de costume, quieto junto à caixa-registradora, em alguns momentos, reclamava de cansaço. Fabiane parecia mais animada, ria muito - me disse que ainda sentia dores no tórax.

* Fabiane e Sabrina atrás do balcão riam muito, o motivo realmente não sei qual era, mas, certamente, tratava-se de algo que a primeira falava. Ela estava elétrica naquele dia: Sabrina, debochada, dizia que ia dar um gardenal para Fabiane tomar. 
* Hoje, segunda-feira, o senhor ex-policial passou na frente da padaria, ao me ver através do vidro da grande janela me cumprimentou: "Oi professor!"

* Um operário, provavelmente de alguma obra das proximidades, lanchava numa das mesas. Augusto acertava preços com uma mulher, algo como o preço do presunto. Ela, por sua vez, enquanto lhe falava batia com a caneta no papel, meio senhora de si, um quê de mulher moderna na sua postura, algo como a vendedora competente de alguma distribuidora de produtos alimentícios. O dono da padaria se afasta para atender alguém no caixa. Só, parece refletir sobre os produtos e os preços manejam a calculadora, confere listas, verifica figuras. Maurício, um dos funcionários, se aproxima meio inconveniente, forçando um diálogo com ela, faz uma pergunta acerca do preço da "copa". Ela pergunta: "fatiada?". Procura o preço e lhe diz. Não lhe dá atenção.

* Seu Vítor, o ex-policial, passa uma vez em frente a padaria, lança um olhar para o interior, mapeia o espaço como quem perscruta o seu território, como quem conhece os detalhes da ambiência e os atores que por ali transitam. Retorna, mas desta vez se aproxima da porta: a entrada da padaria torna-se um local para jogar conversa fora com um amigo do bairro, Paulo o funcionário do edifício em que moro e seu Jorge, o ex-porteiro do edifício - o aperto de mão e a saudação sorridente. Aproxima-se outro homem. Desenrola-se um diálogo que me escapa, não consigo ouvir devido ao barulho e a intensidade das falas durante o mesmo.

* Seu Vítor sofre de insônia. Ouvi dizer que às quatro da manhã já está em pé. Segundo ele, por vezes, sai pelas ruas: "os bandidos nessa hora já foram pra casa!"

* A bicha mulata está ali, tem um visual que poderia se dizer (pós)moderno, discreta, cruza a perna - um ar feminino, nitidamente afetado - lancha com uma colega do instituto de beleza em que trabalha. Levanta, dá uma volta, quase pirueta, olha os doces. Volta e senta com a amiga. Tem a voz com aquele tom afeminado, característico de alguns gays, quase um diacrítico, como um sinal anunciando um tipo de identidade homoerótica.

* Seu Jorge sentou comigo esta manhã para tomar um cafezinho. Acabei descobrindo que ele também é capilé, ou seja, nós dois nascemos em São Leopoldo. Seu Jorge já está há muitos anos em Porto Alegre, mas até bem pouco tempo votava naquele município, segundo ele, teria sido colega de um dos atuais candidatos à prefeitura de São Leopoldo. Conversamos sobre o aumento da violência no Vale dos Sinos e as suas relações com os problemas no setor coureiro- calçadista. 
* Sabrina, sempre muito dinâmica, limpa o balcão de vidro com um pano, observa, realiza metódica movimentos circulares com o mesmo, percorre com a mão as distâncias de uma ponta a outra como quem conhece aquele percurso rotineiro, os segredos daquela superfície, a execução do trajeto. Imprime a força necessária para destituir a possível sujeira do panorama que deflagra os doces.

* Maurício e os demais movimentam-se sem parar atrás do balcão. Há um intenso movimento também do outro lado do balcão, uma circularidade quase enlouquecida no interior da padaria. Os funcionários percorrem o espaço que lhes cabe atendendo as solicitações dos clientes: recolhem os pães numa espécie de armarinho onde permanecem amontoados os pães (cacetinhos), pegam produtos dentro do balcão que mantém refrigerado os objetos perecíveis. A ação quase mecânica de ensacar os alimentos e pesá-los resguarda certo estilo, pois cada um o faz de uma maneira específica: Maurício quer mostrar eficiência e rapidez no atendimento; Sabrina sempre simpática, sorri para os fregueses, ao pesar os produtos olha para eles com certa "distância", Carminha mais lenta, mas sempre disposta, parece realizar suas atividades de forma centrada, como se estivesse profundamente envolvida com as suas atividades. Fabiane, que não estava ali naquele momento, mas que vale a pena comentar é mais alegre, tem uma dinâmica e agilidade na execução de suas atividades que parece ser o reflexo de sua jovialidade. O conjunto é harmônico, a funcionalidade evidente.

* Hoje, ao entardecer, reencontrei Mariana que resolvera "pedir as contas" na padaria, porque seu tio que é alfaiate há muitos anos no Tevah resolveu conseguir-lhe um emprego. Muito falante e, diria, um tanto libidinosa, a jovem me falava uma série de coisas ao seu respeito (que é casada com um homem da minha idade, por exemplo). De repente, Augusto se aproxima de nossa mesa e entrega à jovem a sua rescisão de contrato. Fiquei um pouco constrangido com aquela intimidade, com a negociação trabalhista que presenciava naquele instante. Mariana não sabia o que significava aquele documento - leu fazendo uma cara de incompreensão - e assinou o mesmo. Fez questão de me deixar seu telefone.

* É interessante observar como o ato de abrir a carteira, tão comum, resguarda peculiaridades, na medida que implica em certo estilo de abri-la (até porque existem diferentes formatos de carteiras), de vasculhar seu interior com o intuito de triar e recolher o dinheiro necessário para realizar o pagamento, de introduzir os dedos nas repartições em busca de moedas. Tal dinâmica configura-se num conjunto de ações - parecem tão mecânicas que quase não nos damos conta delas - que assumem formas culturais diversas no interior das camadas médias, ou 
seja, há diferenças em lidar com uma interioridade banal que é o universo de cada carteira, de reconhecimento de espaços e ordenamentos de documentos, papéis e dinheiro, de valores e hierarquias que se referem a lógica dos indivíduos nas sociedades urbano-industriais.

* O bombardeamento de imagens numa padaria causa certo "atordoamento" nos fregueses, pois a estética dos doces, os seus recheios, formas e jogos de cores, quando se apresentam ao olhar que vaga através do visor, por vezes, desencadeia uma interação dialógica entre vendedor e comprador que tem um pouco de auxílio-indução por parte do primeiro, na medida que este dá dicas, que verbaliza as qualidades do produto e aponta com o indicador o mesmo (tal movimento pode se originar do comprador), que direciona e enquadra o olhar daquele que, indeciso, move-se pela necessidade ou desejo de comer, pela saciedade. Mais do que comer com a boca há um intenso comer com os olhos: degusta-se simbolicamente o amarelo-ovo dos quindins, a explosão das bombas de chocolate que detonam a enlouquecida salivação das papilas gustativas; os morangos, pêssegos, figos, kiwis que resplandecem brilhantes na aderência das massas e do imaginário de cada um - são coisas materiais, mas são símbolos da delícia gozosa do paladar, do hábito culturalmente aprendido de comer determinados alimentos. E os cremes, todos ali, também entre as massas, unindo-as, são como a representação do cimento que une o trabalho das pessoas na confeitaria, lá atrás, ao prazer daquele que o compra, ali na frente. Mas os mousses de maracujá também têm o seu brilho, literalmente, banhados pelo líquido amarelado deixam à mostra as pequenas sementes da planta: a presença forçosa de uma natureza distante, uma fruta que de alguma forma representa os trópicos no inverno austral.

* Os salgados, dos folheados às salsichas enroladas em massas, das azeitonas solitárias coroando certos quitutes. Tudo ali, na sua evidência, denunciando a vontade de comer como uma necessidade e um prazer, como um vício e uma possibilidade. Portanto, a pergunta fatídica de Sabrina - "o que vai ser?" - para o rapaz de cabelos longos que observa indeciso, denota que a possibilidade de escolha é um jogo social que mescla desejo (uma oralidade urgente) e diálogo, ou ainda, certa indução. Ele responde: "Ah, esse tem pimentão, né! Beleza! Então vou levar um!".

* A observação dos produtos, sempre panorâmica, de cima para baixo, talvez buscando a totalidade das coisas como elas se apresentam aos olhos, multicoloridas, vibrantes nos seus tons e, porque não, sabores, se dá como uma espécie de dádiva ao olhar que se deleita. Há uma espécie de contemplação dos doces que parece ser quase necessária, mesmo que isso não signifique a compra de um deles, como no caso de um homem que se aproximou do balcão, observou-os atentamente, flexionando um pouco as pernas para olhá-los melhor e exclamou um sonoro "bah!". 
Apesar disso, logo deu as costas e se dirigiu ao outro balcão solicitando um determinado número de cacetinhos, pagou e foi embora. Portanto, os doces que se compra são objetos de interesse de muitas pessoas que por ali passaram ao longo do tempo que permaneceram expostos, ou seja, tratam-se de produtos cujo ato de comprar de alguém é o eco de muitos outros que, porventura, manifestaram culturalmente algum tipo de reação ao vê-los. No entanto, o doce pode significar dor, impossibilidade, como as adolescentes que observavam as delícias existentes, pondo a mão na boca em alguns momentos e exclamando "ais", simulando choro e encostando a cabeça de uma à da outra, devido ao fato, certamente, dos ditames de beleza feminina impossibilitarem que comessem os mesmos, dado o seu caráter óbvio de alterar os números da balança. Após o ocorrido, deslocaram-se até o freezer e escolheram mini-pizzas.

* Nos momentos em que o movimento diminui há uma intensa sociabilidade entre as funcionárias. Nesse dia comentavam sobre a estética dos cabelos e faziam menção ao uso de babosa para melhorá-los. Sabrina comentava comigo que havia sido roubada no dia anterior, ou seja, num bar da esquina da Sarmento Leite com a José do Patrocínio, bem em frente à padaria: furtaram o seu walkman, enquanto, desatenta, atendia uma chamada em seu celular. Carminha perguntou a ela: "como tu foi ratear?". Sabrina apenas fez uma cara de descontentamento e logo foi dizendo "eu não fico sem música!" Fez referência ao fato de encontrá-la diariamente, cedo da manhã, na rua da República "vindo para o serviço" escutando música. Completaria ainda: "Saio daqui e já boto nos ouvidos!"

* Sabrina não resistiu a falta de música, uns dias depois do furto comprou um walkman, mesmo, segundo ela, não podendo fazer gastos.

* Augusto havia me falado do apelido de Sabrina - a cigana. Segundo ela é de origem. Perguntei se lia as mãos, ao me responder que sim, estendi a minha ("que mão fofa!", "sim né, só ergo caneta!"). De acordo com sua leitura viverei muito tempo, visto que a linha da vida em minha mão é longa. "E o amor?", perguntei. "Olha pro lado!", me respondeu. Disse que no outro dia estariam de uniforme novo, o que de fato ocorreu, "tudo de branco, tudo fardado!"

* Enquanto conversavamos, um homem comia um quindim e tomava café preto, o que me pareceu uma mistura esdrúxula. Após a refeição saiu espalitando os dentes. Chegam dois adolescentes, ouço alguém chamá-los de "turma da rapadura", de fato escolhem algumas delas e as devoram com avidez. 
* Uma jovem escolhe algo para comer, pergunta preços, em algum momento passam por ela três funcionários de uma transportadora, dois deles uniformizados, um deles que deveria ser o motorista posto que não estava de uniforme exclama ao passar por ela em tom lascivo, "coisa mais bonita né!". Ela se mostra indiferente, atendendo logo depois o seu celular. Eles escolhem os alimentos que logo comem ruidosamente, banhados por suco de laranja que bebem em grandes goles.

*Um senhor lê o jornal. Fabiane lhe entrega o sanduíche e o café. Come devagar o sanduíche, em seco. Olhar distante, catatônico, sob os óculos de grau com aro preto. No canto da boca persiste um pouco de nata que escorre, mas ele não limpa. Após comer o pão toma o café e, ao final do mesmo faz uso do guardanapo.

*Alguns integrantes do Ói Nóis aqui Traveiz aparecem, pedem um café, segue-se um diálogo acerca de uma propaganda do grupo na televisão. Uma menina que está junto com eles diz que a viu, os demais comentam que não a viram. Pagam e vão embora conversando.

* Carminha me pergunta se sou pintor, Maurício, noutro dia, me perguntaria se eu faço faculdade, digo que sim, "comunicação?" ele pergunta, digo que faço antropologia e pergunto porquê ele acha que estudo comunicação - "ah, por que tem o jeito, estilo!"

* Uma mulher acompanhada de uma menina que segura uma caixa-de-música vende cosméticos e sabonetes para as funcionárias junto ao balcão. Sabrina cheira o pulso (estende a mão para a outra cheirar), comentam algo entre si. Há uma rápida negociação enquanto não aparecem fregueses. Uma outra mulher paga as compras e ao receber o troco conta as moedas, colocando-as dentro de uma niqueleira.

* "Diz dois números de 1 à 80!", exclama Carminha sempre sorridente. Respondo 15 e 27. Ri e diz: "gostei!". Um pouco depois pergunto o porquê dos números e ela me responde que é para jogar na loto ou algo do gênero e que estava sem palpite. Completa: "eu nunca jogo!".

* Um homem entra assobiando, coloca moedas na máquina caça-níqueis, joga. A máquina faz alguns barulhos, luzes piscam. Sai meio desapontado colocando seu dinheiro numa niqueleira.

* Manhã. Digo a Fabiane que vou tirar fotografias dela naquela semana. Me responde rindo que "se tirar foto, queima!".

* Nem todas as pessoas são simpáticas com as funcionárias da padaria, inclusive, algumas vezes, me comentaram da grosseria de certos fregueses para com elas. 
* Uma mulher ao pagar a sua conta bate numa garrafa vazia que estava junto ao caixa, quebrando-a. Reina um constrangimento no ar. Augusto diz "tudo bem!" e ela se vai. Sabrina se aproxima e recolhe os cacos com a vassoura e a pá de lixo.

* A mulher um tanto impaciente puxa o filho que reclama enquanto chora por que quer jogar na máquina caça-níqueis.

* Fabiane está expansiva, alegre: puxa Sabrina segurando sua cabeça, ou melhor, vira a cabeça da colega e lhe dá um sonoro beijo na bochecha.

* Pergunto à Fabiane como vai seu tórax, ela responde com outra pergunta: "Quem?"

* Fabiane olha para a rua e diz "deixa eu arrumar o café pro meu amigo!", Sabrina constata: "ele já vem vindo!". Em seguida Fabiane começa a preparar o café e o sanduíche. Percebo que se aproxima um senhor que cotidianamente toma café da manhã na padaria enquanto lê o jornal. O homem sorri ao ouvir a conversa. Fabiane ao se aproximar sorridente, pergunta: "o jornal também?". Sabrina comenta com ele: "mais um pouco e o café já tá servido!"

* Sabrina me diria que esse senhor "sabe um monte!", que seria um tipo de intelectual professor ou coisa do gênero, que seria "cabeça".

* O tomar café da manhã na padaria representa também um momento para a leitura do jornal. Portanto, ler as notícias do dia reveste-se como uma prática cotidiana que é uma realidade na padaria, ou seja, existem pessoas que têm como hábito matinal tomar o seu café com leite saboreando um sanduíche de presunto e queijo, enquanto realizam a leitura do jornal.

* Seu Jorge conversa com o zelador do edifício em que moro, estão junto ao balcão. Me cumprimenta como sempre com um "bom dia meu amigo! Dia bonito, né!" - diga-se de passagem que todo mundo é tratado como "amigo" por ele. Diz a uma das funcionárias da padaria que vai tomar um pingado - sem jamais esquecer o "minha amiga". O zelador bebe o café rapidamente e vai ao caixa. Diz a seu Jorge que pagou a conta. Há uma discussão sobre quem deve pagá-la, uma certa formalidade, onde ressalta-se que o próximo café é seu Jorge quem pagará ("É meu!... Não, não... Pago depois então!")

* Uma senhora pede um cafezinho (se atravessa no atendimento de um outro cliente). Ao receber o café, responde a pergunta "Açúcar ou adoçante?": "adoçante... eu sou diabética!".

* O homem que comeu um doce fica limpando os dentes com a língua, faz um chiado friccionando os lábios com os dentes - literalmente chupa os dentes. Levanta e vai embora. 
* Tarde. Fabiane me interpela: "O que tanto tu anotas?" e conclui desconfiada "Queres que eu te fale só pra ti anotar aí!"

* Seu Vítor ao me ver: "Daí teacher, tudo bem!" Ao ver Fabiane: "oi sobrinha!"; "que tio!" responde ela.

* Uma mulher que estava sentada junto com o homem, ao levantar se dirige a Fabiane e diz "tu és muito gentil!". Fabiane, rapidamente, volta-se para mim, arregala os olhos e diz "isso tu tens que anotar! Anota aí, anota aí!"

* "Olha o balcão!", eis a frase que seguidamente se escuta de um dos donos do estabelecimento para os funcionários.

* Um cego chega escoltado por uma senhora. Carminha se aproxima, ele pergunta se é Sabrina. A mulher diz que não, que "é uma outra nova!". Depois comenta com ele que precisa "fazer a barba amanhã, até sexta-feira tá enorme!".

* É noite, as pessoas transitam de um lado para outro, a padaria está cheia. Sentamos eu, Ednalva, Talita, o cachorrinho Pingo está junto de nós. Nas mesas próximas a nossa está uma família - o casal e o filho -, noutra dois homens e, numa terceira, duas mulheres. Um dos homens e as duas mulheres fumam incessantemente. Uma delas parece ter problemas psíquicos, algum tipo de perturbação que se reflete na forma de olhar, na lentidão dos movimentos que lembra alguém sobre efeito de tranqüilizantes: entre tragadas afirma meio evasiva, quase sem emoção -

"eu tô de aniversário hoje, 45 anos!". Seguem-se parabenizações por parte dos homens. Um deles, o fumante, também parece possuir problemas similares ao da mulher, mas, ao contrário, tem os olhos meio estalados, um olhar perturbado que não se fixa em parte alguma. A mulher ao fumar, por vezes, olha fixamente para o cigarro, fala daquela forma meio arrastada, como se "enrolasse" a língua. De repente, entre as duplas surge um diálogo acerca dos males do cigarro. A origem da discussão se dá a partir de questões que um dos homens faz a mulher que fala enrolado, ao mesmo tempo que reflete sobre os benefícios de não fumar e comenta coisas sobre a sua boa saúde ("não tenho nenhum problema de pressão, tenho 45 e dou um balão em muito guri novo!") e relaciona isso ao fato de não fumar e nem beber nada de teor alcoólico. A mulher fala lentamente que fizera uma cirurgia num dos pulmões ("Mas então tu não deveria fumar!", afirma ele). A mulher, afirma ainda, um tanto lerda, entre goles de café, que não consome bebida alcoólica, mas que não consegue viver sem fumar cigarros. O homem, fazendo movimentos com os dedos de uma das mãos em direção à boca, sinaliza com os mesmos que não vive sem comer ("eu não vivo sem 
isso!"). A conversa segue entre eles, meio polarizada entre o não fumante e a mulher de fala lenta, os demais são coadjuvantes, falando muito pouco. Nunca tinha visto esse pessoal na padaria, reunidos naquele canto formam um conjunto que Ednalva denominaria de "gaiola das loucas".

* Eu e Davi, um amigo, sentamos para fazer um lanche. Estou um pouco deprimido naquela noite, falo muito, mas a mulher ao meu lado que está com a mãe e a filha me ganha, inclusive na altura da voz. Grita ao falar com a filha, não de forma a repreendê-la, mas por que é um tanto espalhafatosa. Comem com exagero, misturam doces e salgados. Muito gorda e, dada a grande proximidade das cadeiras, bate várias vezes em mim com suas nádegas imensas. Rimos da situação.

* Manhã. Sabrina comenta com Fabiane: "chegou o outro mala!". Trata-se do careca meio gordinho que está todo o dia pela padaria.

* O hábito: Sabrina toma qualquer líquido de canudinho, segundo ela, "é pra não sair o batom!".

* O dilema: porquê Fabiane sempre vira um pouco de café quando serve a xícara? Eis a questão que ela sempre se faz.

* A mulher sentada solitariamente, permanece pensativa após o café preto, parece esperar alguém. Não demora chega uma outra mulher que se junta a ela.

* Manhã. Um bêbado entra na padaria, possui um cobertor sobre os ombros, as roupas um tanto sujas, carrega uma pasta na mão direita. Pede um papel, fala coisas desconexas. Sabrina me diz que é para fechar um baseado. O homem continua falando coisas que não se entende. Parece irritado com Augusto que não lhe deu atenção: "Eu tenho mais dinheiro que ele e tô pedindo papel pra ele!", exclama meio irritado. Ao receber o papel de alguém, sai, mas continua falando sozinho, xingando. Fabiane indignada, me diz que deveria dar "um soco no meio da cara e jogar no chão" o bêbado. Acho graça daquela violência que na realidade é quase inocente.

* Fabiane e Sabrina em um dado momento trocam socos e tapas, mas tudo não passa de pura jocosidade. Simulam brigas e posam para a fotografia.

* Fabiane canta coisas que não compreendo. Pergunto sobre o que gosta de ouvir e logo me diz "adoro pagode!". Segue cantando e dançando atrás do balcão.

* Pergunto a Augusto sobre a quantidade de pães que são produzidos diariamente na padaria. Muito sério, ar um tanto profissional, me responde que o seu estabelecimento produz 
mais variedades de pães do que quantidade (cerca de 2000 cacetinhos diários; 1000 unidades de pão integral, diet e centeio). Segue afirmando que "nós somos uma padaria de balcão. Não é de reparte, não temos interesse de fazer entregas grandes. Abrimos mão. Não temos estrutura para isso!"

* Faço referência a sua importância na padaria, na medida que está sempre sendo solicitado pelos funcionários ou pelo outro sócio (e sua mulher e filha) quanto aos preços dos produtos, ou mesmo, atendendo fornecedores. Me diz que 70 ou $80 \%$ das coisas ali são "com ele".

* Pretende no futuro trabalhar com computação gráfica, com artes plásticas (foi estudante de arquitetura por um determinado período pelo que me consta). Estaria fazendo seu pé de meia para poder mais tarde trabalhar no que gosta.

*Manhã. Estou observando Fabiane e Sabrina brincando, dizendo bobagens uma para a outra - Fabiane chama Sabrina de "anaconda". Dão risadas. Rio ao ver a cena a partir da mesa onde tomo meu café. De repente, ouço Seu Vítor (na realidade nem havia percebido que estava ali) - "Hoje até o professor tá rindo. É porque ele não é professor do Estado, por isso que ele tá rindo!".

* Chega o rastafari com longas tranças sob uma toca. Como de costume vai direto falar com Fabiane, me parece que há um nítido interesse por parte dele com relação a ela: "Oi amiga!". Ela responde: "Fazia tempo que tu não vinhas aqui!". "Eu venho todo dia!", conclui ele.

* Noutro momento ao ver um homem que chega na padaria - ele freqüenta diariamente o estabelecimento - Fabiane afirma "ainda não tem nuggets!". As atendentes já conhecem as preferências dos fregueses que vão sempre ao local. Ele pede um sanduíche.

* A atividade rotineira de preparar o café e os sanduíches, de aquecê-los é uma prática em que todos na padaria estão envolvidos.

* Um outro homem depois de comer dois sanduíches faz "psipsipsi" para Sabrina e estende o braço segurando o prato de louça branca e dizendo "vai mais um pra mim!".

* Ausência: Carminha sumiu! Pergunto por ela e descubro que não trabalha mais na padaria.

*Manhã. Decido tirar fotografias. Elas se mostram um pouco resistentes, mas logo se sentem a vontade e posam para as fotos. Fabiane quer saber se eu vou mostrar o trabalho depois 
de pronto. Digo que vou deixar uma cópia na padaria. Quer saber quem mais vai ler o trabalho. Afirmo que apenas a minha professora. Logo esquece e posa para a fotografia, mais, me indica situações para fotografar: "tira foto delas trabalhando"; "olha a Sabrina atendendo!".

* Está muito frio hoje, mas a manhã nasceu bonita, clara, com aquela luminosidade típica do sol invernal. As pessoas transitam com seus modelos de inverno: casacões, tocas, cachecóis, luvas, calças de lã. Afinal de contas deve estar uns 10 graus centígrados na rua. É sábado, as pessoas vão à feira. A padaria, como sempre, conserva certo movimento, há uma circulação de pessoas, um entra e sai constante.

Procuro sentar próximo da janela para aproveitar o sol que invade o espaço. Um casal senta ao meu lado, nas cadeiras e mesa próximas a minha. Na rua, um mendigo meio calvo e de barba hirsuta está junto a porta - Augusto o chama de Segurança -, pronuncia palavras em tom baixo e fica com aquele seu jeito característico: a cabeça voltada para o lado, meio em diagonal maltrapilho e sujo, com os pés descalços - ele vive pelo bairro. Em um determinado instante pede na porta um café para Augusto. Nunca tinha ouvido a sua voz: é grave, alta, mas se assemelha a uma espécie de lamento, quase gutural. Traz um casaco sobre os ombros - Sabrina me diria que tentou por várias vezes colocá-lo, mas não conseguiu -, Augusto, quase imediatamente, vai até o balcão e serve café com leite em um copo plástico e pega dois sonhos, segue até a porta, traz uma generosidade no olhar, um meio sorriso. A mulher que entra na padaria e, não sabe o que está acontecendo, pede para Augusto dar ao homem algo para comer. O dono da padaria então, diz para ele pegar o café. O homem se afasta, arredio, não quer se aproximar. Augusto desiste por um momento e coloca os alimentos sobre o balcão para atender as pessoas que estão no caixa. Há um envolvimento das pessoas no interior da padaria em torno da questão, uma comoção. O casal ao meu lado discute sobre o assunto. "Ele é esquizofrênico", diz a mulher. Sabrina comenta algo atrás do balcão. O homem ao meu lado decide levar os alimentos ao mendigo. Na rua, solicita que o mendigo venha buscar os alimentos, é inútil, ele se afasta mais um pouco. Decidimos em um diálogo conjunto (a mulher sentada ao meu lado, o homem na rua, Sabrina atrás do balcão Augusto detrás do caixa observa enquanto atende as pessoas) que o melhor é deixar o café e os sonhos junto a janela para que ele resolva por livre e espontânea vontade pegá-los. A mulher que pedira a Augusto para que desse o café a ele sai e tenta falar-lhe, ele escapa, novamente, arredio e cabisbaixo, diz coisas que não se entende. Ela sai meio desapontada. Logo ele vem, como que 
rondando o alimento, um movimento daqueles que lembram um animal rondando a caça (aqui não há nenhum demérito na comparação, mas sim, uma forma de pensar que certos comportamentos humanos são etologicamente semelhantes aos de alguns animais), como que circundando o alimento, cerca-o, e, subitamente, o apanha fugindo com rapidez, para, em algum lugar que julgue adeqüado, comê-lo. Há no interior da padaria uma certa satisfação, olhares são trocados. O homem ao lado diz à mulher "é como um pardal tem medo, mas não deixa de pegar a comida!".

* Noutro dia de manhã Augusto deu-lhe café com leite. Dessa vez aceitou rapidamente e saiu.

* Noite. Eu e Jô tomamos café e comemos doces: falamos acerca da sua defesa de dissertação que ocorreu naquela tarde fria. Há um certo vazio nela, presente naqueles que experimentam a sensação de terem sido argüidos por uma banca. Entra uma loira na padaria, oxigenada, sobrancelhas desenhadas, boca vermelhíssima. O rosto é redondo demais. Meu "olho clínico" logo identifica a travesti. Ao abrir a boca a certeza: a voz é masculina. Senta próxima de nós, come ávida salgados e doces, segurando-os com suas mãos muito grandes. As pessoas percebem algo diferente quando anda, observam com certa desconfiança no olhar: ela, por sua vez, ao olhar os doces se agacha um pouco e empina as nádegas muito redondas. Os homens observam - a curiosidade e o indisfarçável desejo no olhar. Jô diz que "a cara é puro silicone" e Sabrina afirma que "as vezes, é muito mais homem do que muito homem!" . Eu digo provocante: "e que algumas mulheres!". Sabrina me diz contrariada: "aí não!"

* O antropólogo em campo é mais um personagem no teatro social onde pessoas investem naquilo que é o viver em sociedade. Há uma diferença é claro: ele está ali tentando captar e, quiçá, traduzir essa dinâmica cultural, que escapa quase sempre, quando não a olhamos com o olhar inquieto, oblíqüo, que quer perscrutar certos segredos tão comuns que configuram esse viver. Ele está situado e é mais um; ele está curioso e é mais um; ele quer desvendar essa riqueza que se apresenta e é, apenas, mais um: se constrói nessa diferença e é, por isso, que quer dialogar com o outro, porque o outro o seduz, aguça seu olhar e revela o próprio sentido de ser do antropólogo que mergulha naquele intenso jogo de sensações e imagens. Ali, no campo, os papéis sociais se deflagram como a possibilidade de criação a partir das ações/práticas humanas que configuram teias, nas quais as tramas de significados que tais atores constroem em interação permite que o cotidiano assim vivido seja um universo repleto de riquezas e, por isso, passível de ser interpretado. Eis a cultura - essa magnífica capacidade de dar forma ao que é fruto da liberdade humana e que o antropólogo persegue como a si mesmo. 
Sendo assim, o que vivi enquanto um pesquisador que, na realidade, não se afastou sequer uma quadra de onde mora, foi um intenso enlace afetual com pessoas que desconhecia e que me permitiram, ao conviver com elas, perceber que o seu cotidiano traz o encanto quase banal daquelas coisas que nos surpreendem por serem como são. A padaria, agora, faz parte do meu cotidiano de outra forma e, como uma espécie de vício, mesmo que eu tenha café e lanches em meu apartamento, tenho que, sempre que possível, descer e tomá-lo ali, naquele universo que, de tão comum, é singular. 


\title{
ANEXOS - excertos do relato acerca de uma "caminhada etnográfica" no bairro Cidade Baixa
}

\author{
"sabemos inexistir paisagem \\ quando captamos \\ través do fotograma \\ da mente \\ (...) \\ sacar da paisagem o que não existe \\ aprendemos" \\ Flash - Afonso Henriques Neto
}

O bairro Cidade Baixa é um desses locais, onde o cotidiano se reveste de ações bastante comuns, mas que representam um conjunto intrincado de relações humanas, na medida em que existe uma complexa dinâmica de interações sociais que ocorrem no local que, por mais que sejam observáveis em outras cidades brasileiras, ou mesmo, de outros bairros da mesma cidade, parece, neste caso, assumir peculiaridades que são próprias de uma região específica da cidade de Porto Alegre.

Se tomarmos a Praça Garibaldi como ponto de partida para uma "caminhada etnográfica", uma deambulação pelos meandros das ruas que formam a rede urbana que constitui o bairro, para iniciarmos uma espécie de incursão à Cidade Baixa - é possível perceber que cedo da manhã os garis limpam a praça enquanto um mendigo dormita no banco, cabisbaixo numa sonolência despreocupada - onde a presença das pessoas não parece significar qualquer tipo de perturbação a um dormir que é tranqüilo na forma que se apresenta ao olhar de quem o observa muito menos ao burburinho dos automóveis que anunciam mais um dia de movimento na Avenida Venâncio Aires.

A Praça Garibaldi traz consigo uma imponência épica que se apresenta ao olhar através do monumento de mármore de carrara que a praça ostenta: as feições de ambos, Giusepe e Anita Garibaldi, demonstram a saga guerreira de um período turbulento que outrora reinou no Rio Grande do Sul, mas que agora, contrasta com a turbulência do espaço urbano: seus automóveis e businas que simulam uma guerra urbana no trânsito. 
Mas não se trata de demonizar o espaço urbano através dos fantasmas do trânsito, mas de chamar a atenção para que apesar disso, há lugar para o mendigo modorrento dormitar no banco, para as garis varrerem a praça e falar de amenidades, para os joões-de-barro caminharem calmamente por entre o gramado ralo sob as árvores esparsas da praça.

Percorrer o bairro revela ao caminhante a dinâmica de transformação do espaço urbano em Porto Alegre, cuja febre modernizadora que se estabeleceu no final do século XIX e primeira metade do XX, acabou por definir novas feições à cidade, onde uma série de áreas geográficas como a Ilhota terminaram por ser modificadas, urbanizadas, higienizadas através de uma perspectiva encantada pela idéia de progresso que, certamente, desconsiderou a peculiaridade paisagística da região, bem como, os espaços de sociabilidade próprios da população citadina - e aí penso num personagem boêmio como Lupicínio Rodrigues cuja importância para a cultura brasileira é enorme - que ali vivia nesse período.

A região, outrora denominada de Areial da Baronesa, não guarda nenhum resquício do areial, muito menos da Baronesa (a não ser o nome da rua Baronesa do Gravataí) - na verdade os meandros formados pelas ruas dão a idéia de uma área cuja ocupação parece um tanto desordenada, mesclando edifícios com casas mais simples. Não é muito difícil encontrar nessas ruas grupos de pessoas conversando. Aqui faço referência a um especificamente - três homens sentados no meio-fio da calçada mal cuidada (grama meio alta, alguns resíduos dispersos), uma mulher, algumas crianças: "Posso tirar uma foto de vocês?" (Ruben) - após a fotografia (com direito a pose) - "não tem um dinheiro pro velho?". As trocas que são tão importantes para o antropólogo em campo, mais uma vez se mostram como uma realidade negociada.

Ao fim da rua - uma encruzilhada - casas simples, algo que parece com uma oficina de automóveis, o muro longo delimitando a propriedade onde uma mulher conversa com um homem, no que seria a entrada da casa de batuque: um olhar discreto dela, mas curioso sobre os passantes, da mesma forma que nós olhamos e comentamos acerca da placa na entrada do terreiro. Começamos então a observar o que, de alguma forma já sabíamos, que a Cidade Baixa por ter sido um bairro onde havia uma grande concentração de população negra em Porto Alegre preserva em seu corpo uma marca característica de tal influência, ou seja, a presença de inúmeros terreiros de batuque.

A Travessa dos Venezianos, certamente, em função do nome do bloco de carnaval, tem a peculiaridade de um pequeno trecho de rua que nos remete ao século XIX ou início do século XX, 
as casas antigas, geminadas, a rua com paralelepípedos, os postes de iluminação bastante antigos, torneados, nos dão a impressão de estarmos numa Porto Alegre antiga. A presença de um tradicional terreiro de batuque na Travessa torna-a ainda mais representativa na paisagem urbana do bairro.

Ao longo das ruas da Cidade Baixa é possível encontrar pequenas casas geminadas, a maioria delas da década de vinte - como na Rua Lopo Gonçalves - algumas lembrando telhados de casas européias (inglesas), com vidros desenhados com tinta branca, onde destacam-se motivos florais ou alguma ave. A presença de terreiros de batuque também chama a atenção ao caminhante.

A rua da margem, cujo nome evidencia a importância que a paisagem exercia sobre a população, como um tipo de mapeamento do espaço que se dá a partir de acidentes geográficos, fronteiras, daqueles elementos que compõem um ambiente que é transformado pela ação humana. A Rua da Margem não margeia mais o arroio que já não faz fronteira a não ser com uma dimensão de tempo (o que ela foi e o que é enquanto atual Luis Afonso) - com a memória do lugar que está dispersa entre mapas antigos e aquelas pessoas que a conheceram como era, com a presença do arroio que sucumbiu a pressão da Modernidade.

Não se trata de nostalgia de um tempo passado, mas de perceber que o homem configura no espaço físico feições que estão relacionadas a sua ação, um tipo de manejo dos seus componentes que pode desconsiderar vínculos profundos de uma identidade com o lugar, de experiências peculiares de existência humana num dado ambiente.

$\mathrm{Na}$ rua Luis Afonso persiste com imponência o casarão do século XIX, com suas fundações portentosas e firmes, cujas estruturas demonstram a bonança de um tempo onde alguns homens detinham poder econômico suficiente para construir casas que parecem fortalezas, manter escravos e, certamente, laços político-ideológicos com outros poderosos. A edificação persiste como museu que resguarda fragmentos de um passado.

Por outro lado, o Orfanato Pão dos Pobres aparece como uma construção que preserva a beleza arquitetônica do bairro, seus arcos, os corredores longos, o segundo piso e suas janelas compridas - uma delas semi-aberta deixava a mostra duas vassouras das que se esfrega o chão, numa imagem singela do cotidiano do lugar - o sino de bronze, rústico e antigo, descansava num silêncio que só ele sabe romper. 
Os meninos entretidos no jogo de bola corriam e gritavam, enquanto um cheiro de comida inundava a ambiência anunciando que logo mais o almoço seria servido.

A caminhada etnográfica culminou nos antiquários. A porta chaveada, uma "bicha" austera nos recebe (depois ela limparia metódica um lustre de cristal, sensível, e só depois se mostraria simpática a nossa presença) deixando a mostra um pouco da riqueza estética das obras humanas: as obras de arte, a delicadeza das formas, o contorno dos corpos, a beleza das gravuras, a imponência dos objetos; os cristais e o brilho da luz refletindo neles; a sutileza da indústria moveleira talhando na madeira as marcas de um tempo. Tudo ali é encantamento ao olhar que aprecia o belo, a sutileza das formas estéticas e sua dinâmica ao longo do tempo, frutos da criatividade humana.

\title{
Um breve olhar sobre a Cidade Baixa
}

\author{
"Ponha uns óculos escuros \\ e saia por aí. Dando bandeira" \\ Tira-teima - Bernardo Vilhena
}

Existe na Cidade Baixa algo que me encanta e, por isso, me lança numa deriva pelas ruas, no meu deslocamento desvelo seus segredos microscópicos, suas sutilezas e nuances tão próprias de um espaço urbano dinâmico, ou seja, caminho e sei que pertenço àquela paisagem como mais um entre tantos, mas há em mim (e certamente não sou o único) um olhar que quer perceber bem mais que um mero acúmulo de prédios, de trânsito desordenado de pessoas. Ali pulsa uma espécie de vida tresloucada, de um sem número de transeuntes dispersos pelo espaço que constróem através de suas trajetórias a dinâmica que vibra no lugar.

Caminhar pela Cidade Baixa é percorrer uma porção de Porto Alegre que contém a singularidade de ser uma área que resguarda certa relação com a boêmia, portanto, há nela pelo menos dois ciclos, com dinâmicas diversas, ou seja, há uma Cidade Baixa que tem a ver com um ciclo mais diurno, onde reina a família, o jogo de bola, a brincadeira de roda, o passeio com cachorro, as vovós e vovôs, a escola, os sabiás e cambacicas sobre os jacarandás. 
Por outro lado, há um ciclo noturno, no qual os cafés e bares funcionam como espaço de sociabilidade, cuja movimentação se inicia com o entardecer e culmina com o amanhecer no Van Ghogh, por exemplo. Na noite, os corpos circulam pelas esquinas, quase caça ou mesmo ela, quando tudo desemboca na Redereca (a gíria que denomina a Redenção entre os gays), uma violência mais virtual que real, mas a potência dela nos forçando a uma cultura do medo quando a avenida é habitada por pessoas incógnitas cujos gritos e palavrões (que escuto de meu apartamento) me despertam, de sirenas rasgando o corpo da madrugada, de freios insistentes que produzem insegurança na hora de atravessar a avenida.

Mas existem personagens que caotizam os ciclos, posto que transitam num nomadismo urbano, onde a casa e a rua se fundem e se confundem, habitando calçadas, vivendo junto a portas de edifícios, me parece, portanto, que para eles os ciclos são, de certa forma, intermitentes, no sentido que não há uma divisão do tipo família/boêmia (ainda que tal divisão seja arbitrária). Os habitantes da Cidade Baixa são diversificados e experimentam formas diferenciadas de viver o espaço urbano, de explorar as possibilidades que ele oferta àqueles que buscam nele um motivo para estar-junto, para interagir no meio urbano.

\title{
O cotidiano da Cidade Baixa, um olhar estranhado sobre o familiar: deriva, paisagem urbana e a gente no bairro
}

\author{
"teu olhar flutua \\ onde olho" \\ The Plot Thickens - Vera Pedrosa
}

A escolha pela divisão em ciclos (diurno e noturno) não é nova, Hélio Silva a fez de forma brilhante em seu Travesti - A invenção do feminino e, por outro lado, pode remeter de forma tímida aos regimes diurno e noturno propostos por Durand, no entanto, nesse caso, remete a dinâmica própria das cidades, ou seja, a ocupação de nichos espaciais e culturais ao longo do desdobrar microscópico do tempo, de ritmos numa duração onde grupos se sucedem na ocupação do espaço durante o curso do mesmo - no sentido do cotidiano, do dia a dia que desponta com o amanhecer para se perder nos meandros da noite - demarcando territórios, compartilhando sentidos entre grupos humanos que por ali circulam. 
Para as observações (muito breves) que estabeleço darei ênfase basicamente ao trecho que vai da Rua Sarmento Leite até o Nova Olaria (dando maior atenção a rua da República) onde o meu deslocamento no bairro é mais intenso.

\section{Dia}

"os dias voam comigo nas asas"

Charles

A rua da República logo cedo da manhã já apresenta um significativo fluxo de pessoas, pois trata-se do percurso diário da casa ao trabalho/escola (que se inverte ao final da manhã ou ao entardecer), certa velocidade no passo, um pai ou uma mãe conduzindo o filho ainda sonolento para a creche é algo bastante comum. As lojas começam a dar sinal de vida lá pelas 8:30 hs, quando já é possível observar as pessoas (homens ou mulheres, jovens e idosos) levarem seus cães para passear - são de todos os tipos, das mais variadas raças (ou sem raça nenhuma), mas o que salta aos olhos é o tipo de ethos que essas pessoas possuem, ou ainda, o que parece ser um tipo de humanização dos cães (uma senhora me disse um dia quando vi sua cadela basset e falei da beleza e da gordura da mesma - "ah, ela veio do médico, tem 25 quilos está de dieta, fazendo regime. Também ela não pára de comer! Quer ver!" e soltou um pouco a corda para que a cadela seguisse - a gorducha foi direto num pacote de salgadinhos jogado no chão e ficou chafurdando nele, mostrando que seus hábitos alimentares são bastante ecléticos.

Portanto, um detalhe significativo para os transeuntes menos avisados que perambulam pelo bairro é o fato de que transita-se num campo minado de excrementos animais (quando não humanos), ou seja, as pessoas levam seus cães para passear e dispersam excretas no espaço urbano como um subproduto da sociabilidade canina. Muitas vezes vi pessoas se aproximarem para conversar a partir do contato entre os seus cães, portanto, uma boa farejada mútua pode gerar uma amizade entre os seus donos.

Na República há uma clínica e loja de produtos veterinários que possui desde os remédios até consumismos de vários tipos para cães e gatos. A clínica parece muito movimentada, um fenômeno antropológico interessante e passível de análise mais profunda, onde um certo tipo de visão de natureza mescla-se com a sociedade de consumo. 
No edifício em que moro muitos moradores possuem cães e gatos - um dia desses vi uma garota subindo no elevador com um filhote de boxer que já era grande, imagina quando crescer! Na Rua Sarmento Leite há uma caturrita que voa de janela em janela, não sei se pertence a alguém, mas parece ter um trânsito fácil pelas janelas dos edifícios.

A Cidade Baixa neste trecho que tomei como locus de observação é extremamente agitada ao longo do dia, pois devido a proximidade com o centro da cidade há um fluxo muito grande de automóveis, portanto, não é raro que aconteçam acidentes na esquina da República com José do Patrocínio - ocasionalmente escuto o barulho da batida e vejo pela janela do edifício pessoas conversando, discutindo como ocorreu o acidente.

No entanto, as crianças tomam conta das calçadas e brincam com uma liberdade surpreendente as vezes, para um ponto movimentado como é este, pois em meio a certa agitação há espaço para a sociabilidade infantil: pular sapata, brincar de pegar, jogar bola, brincar de roda, andar de skate. Algumas crianças estabelecem seu pequeno "território" bem próximo da esquina da República com a José do Patrocínio, junto a uma associação de cegos que existe no local.

$\mathrm{Na}$ mesma esquina os jovens em pequenos grupos (por vezes tribos distintas - rappers, moradores do bairro, grupos de meninos e meninas) se reúnem para conversar, sentados junto a porta dos edifícios próximos de uma sorveteria. Ainda, dependendo do grupo, suas conversas podem ir até quase a madrugada.

Do outro lado da avenida, portanto na esquina oposta, os taxistas interagem entre si, rindo e falando alto, encostados aos seus automóveis (ou dentro deles), sentados em um banco que por ali permanece demarcando seu território. É um número significativo de homens, ou seja, trata-se de um espaço de sociabilidade masculina, o que não significa que, ocasionalmente, apareça uma mulher no local e ali permaneça conversando.

A República, em especial, é uma rua onde os transeuntes podem ser moradores do bairro ou pessoas de passagem em função do trabalho, mas me parece que a maioria dos que transitam no local são moradores. Há nela certo ar de interior, de singeleza interiorana, com seus paralelepípedos e casas antigas mescladas a certa modernidade nos edifícios, nas lojas, nas roupas dos passantes, além disso, existem indícios de tradições orientais - há lojas de produtos da Nova Era - por isso odores de incenso se difundem por alguns pontos da rua. E mais, há os jacarandás da República e os seus sábiás-laranjeiras cantando alto desde a madrugada. 
O Nova Olaria na Lima e Silva, nos domingos, é o local dos modernos, mistura de famílias classe média com os gays que ostentam roupas "fashion" (entenda-se de marca, modelitos prestigiosos) - o "Bibódromo" como dizem, pois é freqüentado pelas "bibas" que consideram o Nova Olaria aos domingos à tardinha o ponto alto da "Cidade Bixa" (como se diz no gueto). O lugar aparece no mapa do Nuances como um dos pontos de encontro do povo gay da cidade.

\section{Noite}

"A noite se aproxima."

Fim de dia - Vera Pedrosa

$\mathrm{Na}$ noite todos os gatos são pardos, pois quando os sabiás vão dormir é a vez dos morcegos saírem para passear (e como têm morcegos voando entre os edifícios). Ao anoitecer a Cidade Baixa toma outro aspecto: os cafés que começam a abrir à tardinha recebem um público de classe média, de estudantes universitários, de pessoas que se reúnem após o trabalho para bater um papo sentados junto as mesinhas espalhadas pelas calçadas. O som geralmente é clean - MPB de boa qualidade ou um rock sem grandes barulhos ou dissonâncias de guitarras. Ali as pessoas bebem café obviamente, mas também cerveja.

Durante as primeiras horas da noite é possível ver algum morador do bairro passeando com seu cão pela rua, conversando com alguém - na República, as pessoas param para conversar, calmamente, coisa que seria quase impossível no centro da cidade dada a sua costumeira agitação.

O inusitado também é possível, na medida que se apresenta como o insólito encontro com a "concretude" de personagens teatrais, com a performance do grupo Ói nóis aqui traveiz no seu Hamlet Máquina, pois o espetáculo inicia-se na rua, portanto, não é difícil ver os atores realizando os ajustes dos seus figurinos para logo começarem a sua encenação, ali, na calçada: o figurino gótico, medievo, onde roupas negras, longas, faces pintadas em cabeças que sustentam chapéus com véus roxos, atores sobre pernas-de-pau -, um homem sentado numa espécie de trono é conduzido para dentro do ginásio -, ao som de um bumbo e de um prato que batem com certa monotonia ao mesmo tempo que os atores dão longos passos, ritmados, acompanhando a sonoridade monocórdica dos instrumentos, trata-se de um cortejo fúnebre. 
Por outro lado, na esquina da José do Patrocínio com a Sarmento Leite existe um bar com aspecto bastante precário (ouvi dizer que é boca de fumo, mas não tenho certeza), meio escuro quando se vê de fora, que assim como o Van Ghogh, tem um público mais underground - uma "fauna" urbana - e fecha geralmente quando está amanhecendo - me parece que abre de segunda a segunda.

A medida que a noite avança é possível encontrar as pessoas que se dirigem para os bares (Jardim Elétrico e Ossip na República/Zelig e Casa do Teatro que ficam na Sarmento), freqüentemente topa-se com artistas locais de teatro. Um ponto importante de encontro é o Bar do Beto na Sarmento, onde as vezes é impossível conseguir uma mesa para jantar.

No encontro da Lima e Silva com a Rua Sarmento Leite reinam os bares com cadeiras na rua (Cotiporã e assemelhados), diferente da República, trata-se de grande número de pessoas, que falam alto, misturando sonoridades musicais, bebe-se muita cerveja e o prato característico é o "xis". Há, por vezes, uma deriva de bar em bar que as pessoas realizam e que pode estar relacionada a um mapeamento do público freqüentador, no sentido de encontrar alguém conhecido ou interessante para flertar.

Mas, o bar mais significativo me parece ser o Van Ghogh, reduto de uma boêmia underground: misturam-se ali os diferentes tipos humanos - a sua posição na esquina da República com a João Pessoa - já sinaliza para um espectro maior de freqüentadores que atravessam os meandros da Redenção, que percorrem os bailões da João Pessoa. Ou seja, pode-se encontrar ali os estudantes moradores da Cidade Baixa, os travestis e gays que perambulam pela noite. A sopa do Van Ghogh é famosa. Ali estratos sociais e etnias mesclam-se até o amanhecer. Nas manhãs que tenho aula passo pela frente do bar e ele ainda tem um público considerável bebendo cerveja, tomando sopa, conversando, conversando...

\section{Do nomadismo}

em cada pirado em cada pivete em cada malandro em cada suicida em cada sub/urbanóide eu vejo todo o seu esplendor escorrendo pelos bueiros desta cidade vazia..."

Adauto 
A Cidade Baixa tem muitos nômades urbanos -, maltrapilhos, eles vagam pelas ruas, dormem pelos cantos sozinhos ou agrupados, comem o que lhes dão e jogam os restos pelas calçadas - conheço vários deles de vista.

A relação dia/noite, logicamente, existe para tais pessoas, mas o que me parece é que a sua permanência na rua faz com que a sua dinâmica seja outra: nem aquela do burguês que dorme trancafiado com a família dentro de casa, nem a do boêmio que passa a noite enchendo a cara e jogando conversa fora na mesa de bar.

$\mathrm{O}$ fato de perambularem pela rua fazendo dela a sua casa, não significa que não possuam territórios. Há, por exemplo, uma moradora de rua que vive junto a porta do meu edifício - Isabel - dizem que ela era moradora do prédio, mas teria "pirado" e "ficou assim" como me disse o porteiro. Ela fica sentada ou deitada com suas coisas, bem próxima da porta do edifício. As vezes fica sentada, mas jogando o corpo para frente e para traz, dizendo coisas pouco compreensíveis. Ri desdentada para os que a conhecem, mas não hesita em xingar se a importunam. Uma vez a vi semi-nua lavando seus órgãos genitais com a água de uma bacia, noutra ocasião ela estava nua, recém saída do banho no lago da ponte dos Açorianos. Eis a "sereia dos Açorianos".

Há, entre tantos, um outro morador de rua que é travesti, trata-se de um homem negro de cerca de trinta e poucos anos, com problemas mentais, que anda de salto alto, saia e bustiê perambula pela Cidade Baixa e pelo Centro. Seguidamente tem um forte cheiro de álcool. É pacato e todas as vezes que o vi estava perambulando solitário pelas ruas. A Cidade Baixa, em sua riqueza, é um cenário muito especial onde uma série de atores sociais participa do espetáculo cotidiano que é, exatamente, como a vida se apresenta em seu esplendor e em sua miséria. 


\section{REFERÊNCIAS BIBLIOGRÁFICAS}

BENJAMIN, W. A Paris do Segundo Império em Baudelaire. In: KOTHE, F. R. (org.). Walter Benjamin. São Paulo, Ática, 1985.

DURAND, G. As estruturas Antropológicas do Imaginário. Lisboa, Editorial Presença, 1989

HOLLANDA, H. B. de. 26 Poetas Hoje. Rio de Janeiro, Aeroplano, 1998.

PERLONGHER, N. Territórios Marginais. Primeira Versão. Campinas, IFCH/UNICAMP, n.27, 1991.

POE, E. A . O Homem da Multidão. In: Os melhores contos de Edgar Allan Poe. São Paulo, Circulo do Livro, s/d.

SILVA, H.R.S. Travesti a invenção do feminino. Rio de Janeiro, Relume- Dumará/ISER, 1993.

Certas cariocas: travestis e vida na rua no Rio de Janeiro. Relume-

Dumará/Prefeitura, 1996.

SIMMEL, G. "A metrópole e a vida mental". In: VELHO, O . (org.) O fenômeno urbano. Rio de Janeiro, Zahar, 1979.

VELHO, G. A utopia urbana. Um estudo de antropologia social. Rio de Janeiro, Jorge Zahar Editor, 1989.

.Projeto e metamorfose. Antropologia das sociedades complexas. Rio de Janeiro, Jorge Zahar Editor,1994a

Individualismo e cultura. Notas para uma antropologia da sociedade contemporânea. Rio de Janeiro, Jorge Zahar Editor,1994b. 